\title{
Proceeding
}

Supplementary Issue: Spring Conferences of Sports Science. Costa Blanca Sports Science Week, 26-28 April 2018. Calpe. Alicante, Spain

\section{The core curriculum in the university training of the teacher of physical education in Italy}

\author{
FRANCESCA D'ELIA ${ }^{1}$, FILOMENA MAZZEO², GAETANO RAIOLA ${ }^{1}$ \\ ${ }^{1}$ Department of Human, Philosophical and Educational Science, University of Salerno, Italy \\ 2Department of Science and Technology University "Parthenope" of Naples, Italy
}

\begin{abstract}
Structural, organizational and normative developments in the school setting in Italy, in the last fifty years, suggest that teachers role should be considered throughout the social, cultural and scientific innovations that lead these changes. Based on this theoretical proposition, the purpose of the present study was to identify some key elements of Physical Education Teacher Training Core Curriculum in Italy. The study takes a documental-based approach to the development of teaching skills and lists action supported by Italian Ministry of Education in the last decades to foster adequate teacher training programs, with particular reference to Physical Education teacher training in the low and high school, since the earlier courses in $18^{\text {th }}$ century till now. The results revealed that teacher training programs in Italy sometimes lacked of adequate methods and significant contents, so it is very important to underline the value of a new approach in teacher training that aim to ensure the acquisition of key competence, according to Recommendation of the European Parliament and to create a cooperation between University and the Italian Olympic Committee. In conclusion, a new approach in teacher training could foster a broad advance in specialization and professional development of physical education teacher, adjusting our educational path to the European best practices. Key words: PHYSICAL EDUCATION, CORE CURRICULUM, TEACHER, ITALY, UNIVERSITY.
\end{abstract}

\section{Cite this article as:}

D'Elia, F., Mazzeo, F., \& Raiola, G. (2018). The core curriculum in the university training of the teacher of physical education in Italy. Journal of Human Sport and Exercise, 13(2proc), S413-S420. doi:https://doi.org/10.14198/jhse.2018.13.Proc2.25

Corresponding author. Department of Human, Philosophical and Educational Science, University of Salerno, Italy.

E-mail: fdelia@unisa.it

Supplementary Issue: Spring Conferences of Sports Science. Costa Blanca Sports Science Week, 26-28 April 2018. Calpe. Alicante, Spain.

JOURNAL OF HUMAN SPORT \& EXERCISE ISSN 1988-5202

(c) Faculty of Education. University of Alicante

doi: 10.14198/jhse.2018.13.Proc2.25 


\section{INTRODUCTION}

Structural, organizational and normative developments in the school setting in Italy, in the last fifty years, suggest that teachers' role should be considered throughout the social, cultural and scientific innovations that lead these changes (Crivellari, 2004). The figure of the first and second grade secondary school teacher has been defined and evolved according to the changes (Gaetano, 2016, Tiziana et al, 2017) that have gone through and characterized the Italian school and training preservice (Lautenbach \& Antoniewicz, 2018) also about inclusion processes (Michael et al, 2018), its pedagogical-didactic theories-practices (D'Isanto, 2016, D'Isanto \& Di Tore, 2016, Di Tore et al, 2016), its organizational structure as well as its educational and social role. (Santoni et al., 2011). The institutional, scientific and cultural definition of the teacher function, starting from its specific training (Sinclair \& Thornton 2018, Kwon et al, 2018, Keating et al, 2017) and passing through recruitment procedures appropriate at the needs of the school system, represents one of the most complex challenges for current governance systems in order to contribute to a real effectiveness of educational processes (Raiola, 2017, 2013, Raiola \& Di Tore, 2017). The availability of an appropriate number of teachers adequately prepared compared to the required profile has probably always been one of the critical points of the various regulatory measures of school reform and teaching (Gaetano, 2012). In fact, currently coexist, professors who, have been trained and recruited through very different paths and procedures, for the same teaching and methodological competences required in today's school. We move from the obsolete conviction that to teach we need only a thorough disciplinary knowledge, at the need of integrate at specific disciplinary knowledge the skills and competences professional to teach to learn. Therefore, there is a need, in an age dominated by the scope and speed of change in the various fields of knowledge, by the changed possibilities of access to disciplinary contents, etc. that make the knowledge acquired in the school context easily surmountable, of aim at transversal skills that make students able to use and optimize the knowledge acquired in the formal paths of the individual disciplines. The recommendation of the European Parliament and Council concerning the eight key competences (Parliament and the European Council, 2006) turns out to be, in fact, the expression of an unequivocal attention to the educational problematic in the broad sense and also for physical education and sport (Altavilla et al., 2017). In the context of the organic measures for the training and recruitment of teachers, particular attention deserves the field of motor and sports sciences that preside at the teaching of physical education in secondary school of first grade and of motor and sports science in secondary school of second grade. It is attributable to the specificity of the teaching contents and methodologies and to the evolution of the founding principles of teacher training courses that has led to the definitive affirmation universitary education to teaching as an indispensable condition for the retraining of the teacher professionalism and the whole formative system. Based on this theoretical proposition, the purpose of the present study was to identify some key elements of Physical Education Teacher Training Core Curriculum in Italy. The study takes a documental-based approach to the development of teaching skills and lists action supported by Italian Ministry of Education in the last decades to foster adequate teacher training programs, with particular reference to Physical Education teacher training in the low and high school, since the earlier courses in $18^{\text {th }}$ century till now. The present work therefore aims to identify some fundamental aspects of the training programs of teachers of physical education in Italy, basing on a study of ministerial documents and normative devices which, from the early nineteenth-century formative experiences, led to current scientific-cultural and social configuration.

\section{Short historical excursus}

From the figure of the pedagogue who presided institutionally to physical education in ancient Greece, passing through the gymnast who, in ancient times, designated those who taught gymnastics, up to the most modern figures of physical education teachers, more systematically delineated in Europe. Starting from the 18 th century, we are witnessing a scientific and cultural evolution of the physical education motor and sportive 
that has invested the role of the teacher, also due to the extraordinary theoretical-practical flourishing of the European schools of physical education (remember to example schools: French, German, Swedish, English, Italian) that produced practices that, although different from each other and sometimes in antithesis, gave impulse to the experience motor, gymnastics and sportive as a positive dimension of the training processes of the person (UImann, 2004). And it is precisely the valorisation of the activities of movement in their different forms in the school contexts that gives strength to the reflection on the training of teachers appointed to these teachings. In Italy the first experiences of training of teachers of physical education date back to the first half of the nineteenth century at the Schools of Physical Education in Bologna and Turin. The bolognese school attributed to the physical education a formative value that was supported and spread by the most illustrious exponent of the age, Emilio Baumann, a primary school teacher and doctor who, from the beginning of his activity, tried to study the relationship between physical education, medicine and hygiene. Gymnastics according to Baumann had to develop physical, intellectual and moral qualities to achieve perfect harmony between the parties. These ideas would have formed the basis of what Baumann will call "psychokinesia"(Baumann, 1886), education of the spirit through the body. Another aspect in which Baumann pioneered very importantly concerned the preparation of gymnastics teachers: a gymnastics school was to train not masters, but gymnastics teachers, that is, people who had chosen to dedicate their whole life to this activity and who had a general knowledge, not only of the basic gymnastics, but also of all sportive disciplines; all this was possible by transforming the normal gymnastics schools into universitary institutes. Baumann, a teacher of gymnastics, had achieve appropriate training when he was able to acquire:

- $\quad$ basic knowledge, therefore notions of human anatomy, physiology and hygiene;

- pedagogical knowledge;

- $\quad$ specialized knowledge of different gymnastics systems;

- $\quad$ knowledge about the historical evolution of gymnastics;

- practical and internship experiences.

The Turin's school was founded, instead, on completely different purposes, encouraging the development of a militaristic type of physical education thanks to the work of one who was considered the founding father of Italian gymnastics: Rodolfo Obermann. He favoured the application of a military gymnastics which aimed to provide the soldiers with a basic gymnastics knowledge, adaptable to all bodies, which would allow the development of strength, fluency and courage. Despite the militaristic character of gymnastics, Obermann also favoured the development of female gymnastics as women could practice physical activities that went beyond the dimension of dance, considered at the time one of the few activities that women could practice. In 1878 Francesco De Sanctis is the promoter of a norm that opens the way to a teaching characterized by highly educational purposes even if the military nature of gymnastics remains; after having redefined the discipline, renaming it "educational gymnastics", which at the end of 1800 became "Physical Education", emanates a law that deals entirely with the subject (Law n. 4442), which makes teaching of educational gymnastic in schools compulsory and which establishes the compulsoriness the teaching of educational gymnastic even for women in schools of all grades. This law states, however, that the programs are agreed on the basis of a close confrontation between the Minister of Education and the Minister of War, and decrees that the teachers are recruited from the military personnel. In the early years of the 20th century, it was made obligatory, at university students of any faculty who had aspired to a middle school diploma, to attend special master classes in physical education at the respective medical faculties, while the normal gymnastics schools of Rome, Turin and Naples were transformed into institutes of teaching for abilitation at the teaching of physical education. In 1923 there was a structural reform of the Italian school system developed by the neoidealist philosopher Giovanni Gentile in collaboration with the pedagogist Giuseppe Lombardo Radice; this law, established by the legislative decrees issued by the government by virtue of the delegation conferred by 
Parliament, redraws the conceptual and operational structure that will characterize the Italian school formally until the beginning of the 60s. Specifically, although physical education occupies an interesting position within the strict pedagogical system of Gentile (Gentile 2004,1993,1990), since the education of the body is aimed at forming the moral character and the will of each student and the body is considered in its spiritual essence, it is spun off from secondary school programs, even if it continues to be present in the program for preparatory and elementary schools and magisterial institutes; providing that the pupils of all governmental schools and matched employees from the Ministry of Education will complete their physical education at the designated gymnastic and sportive clubs (Pasqualini, 2014). During the Fascist period, therefore, the teaching of physical education, characterized by a strong nationalist and paramilitary ideological model (Ponzio, 2008), is assigned to extra-scholastic bodies (Ledeen, 1969), such as the National Body for Physical Education (ENEF), the National Opera Balilla (ONB) and the Italian Youth of the Littorio (GIL). The collapse of the fascist regime (Cassata \& Building, 2011), in 1943, drags all party organizations with it: after twenty years, physical education returns to the Ministry of Education, in terms of discipline; the emancipatory process from the ideological-military models of the previous period is, however, slow and difficulty: the ascending and descending phases that alternate in this process are outlined thanks to an analysis of the meanings attributed to physical education in teaching programs and in disposals that have occurred over time. After the cessation of the Fascist physical education academies for about a decade, no institution took over its functions until the academic year 1952/1953, when the Institute of Physical Education of Rome (ISEF) began to function. The establishment of similar statal institutions was also planned. On the basis of this provision, the following ISEFs were set up in Turin (1959), Naples and Bologna (1960), Florence (1963), Milan (1964), Palermo (1965), Perugia and Urbino (1967), of the Lombardia based in Milan and L'Aquila (1968). The regulation of the ISEFs included three-year courses of study divided into distinct male and female sections. At the end of these courses the students received a physical education diploma, a qualification required for the teaching of physical education in secondary schools. The accessed at course was by contest and based on the number of posts annually defined by the Ministry of Education. At contest, could take part candidates with a secondary education qualification valid for enrolment in degree courses. The ISEF had the task of promoting the progress of the sciences applied to physical education and of providing the scientific and technical culture necessary for the preparation and improvement of those who wished to dedicate themselves to the teaching of physical education and to technical employments in sportive field (law n. 88, 1958), and for over fifty years they have represented the formative way to teach physical education in the first and second grade secondary school, leaving the other training activities at CONI and the National Sports Federations.

\section{The recent history of the training of teachers of physical and sports education}

Legislative Decree n. 178, 8 May 1998, provided the "Transformation of the higher institutes of physical education and institution of faculties and degree courses and diploma in motor sciences, in accordance with Article 17, paragraph 115, of the Law of 15 May 1997, n. 127" (legislative decree, 1998). In its first configuration, the four-year degree course in motor sciences was aimed at acquiring adequate knowledge of cultural, scientific and professional methods and contents in the following areas:

a) didactic-educative, aimed at teaching in schools of all grades;

b) of prevention and adapted motor education, aimed at subjects of different ages and subjects with disabilities;

c) technical-sportive, aimed at training in the various disciplines;

d) managerial, aimed at the organization and management of sports activities and structures.

Following the reform of the Italian university, promoted by Minister Berlinguer, who introduced the " $3+2$ " system, a three-year degree to be followed, in some cases, a two-year specialist / magistral degree instead 
of the old four-year degree courses or five years, also this degree course has been approved in $3+2$ mode, i.e. 3 years of basic degree ( 1 level) and 2 years of second level degree (today masterly) II level, providing for three different courses: Preventive ( Preventive and Adapted Motory Activity), Economic-Managerial (Management of Motor and Sports Activities) and Scientific-Technical (Sports Science and Techniques). The establishment of the degree courses in motor sciences, replacing of the ISEF, at the end of the twentieth century normalized a more widespread alignment of the training and recruitment modalities of secondary school teachers who, in addition to the masterly degree, foreseed an abilitation course for the teaching, achieved through the Secondary School of Specialization Schools (SISS from 1999 to 2009) which included two-year specialization courses within the academic organizations and through the Active Training Internship (TFA AA 2011/2012 and 2014/2015) with annual courses of 60 ECTS and finally, at the same time as the TFA courses, the Special Enabling Paths (PAS) are compacted and free from the CFU system for particular categories of teachers (precarious workers). In their different configurations the specialization courses did not provide for specific study plans defined at national level, the only structure given by the Ministry concerned the generalist dimension (didactic and pedagogical disciplines) and specialistic (motor and sports disciplines) of the paths, without defining specific learning objectives and leaving to the discretion of the universities that activated the paths and the teachers who were entrusted with the teachings and the laboratories the responsibility for planning the training path. It is worth mentioning that in the transition between the Specialization Schools for Secondary Teaching (SISS from 1999 to 2009) and the Active Training Internship (TFA AA 2011/2012 and 2014/2015) with annual courses of 60 CFU and finally, at the same time at the TFA courses, the Special Enabling Paths (PAS) there was an important legislative provision which, however, was not applied, despite it was probably the systemic solution of the problem of the whole teacher training (DECREE 10 September 2010, $\mathrm{n}^{\circ}$ 249). Regulations concerning: «Definition of the discipline of the requisites and modalities of the initial training of the teachers of the kindergarten, primary school and secondary school of first and second grade, according to article 2, paragraph 416, of the law December 24, 2007, n. 244». It contained the training paths of teachers from kindergarten to secondary school with the timely predisposition of masterly degree planes of study for teaching. For political will of the time, the application was first suspended and then the decree was applied for the training of teachers in the nursery and primary school.

\section{RESULTS}

The results revealed that teacher training programmes in Italy sometimes it lacked of adequate methods and significant contents, so it is very important to underline the value of a new approach in teacher training that aim to ensure the acquisition of key competence, according to Recommendation of the European Parliament (2006) and to create a cooperation between University (actually the only agency in Italy authorized to offer specialization to teaching) and the Italian Olympic Committee. Currently the system of training and at the teaching abilitation, as well as the procedures for recruitment and assumption of teachers, is governed by the provisions of Legislative Decree 59 of 2017. This decree has disposed provisionally two different recruitment methods for already abilited or temporary teachers through a detailed multi-year absorption plan.

The new system of recruitment, given the foreseeable simultaneous extinction of precariousness in Italian secondary school, called Initial Training, Internship and Insertion (FIT), provides an initial recruitment procedure on a territorial basis on a prior recognition of the real needs for the introduction in the role that, after a three-year course of specific methodological-didactic training and internship, and substitution temporary first and then annual, then allow aspiring teachers to achieve the role at time undetermined. The requisites required to access the FIT are the title of study (and any exams / credits) expected by the new regulations of the competition classes (Presidential Decree 19/16 as integrated and amended by Ministerial Decree 259/17) and 24 CFU in the anthropo-psychic-pedagogical disciplines and in the teaching 
methodologies and technologies. result, therefore, a systematic planning of the preparatory courses for the FIT is strategic, with particular reference to the disciplinary contents and objectives of the teaching related to the Scientific-Disciplinary Sectors of the Methods and the teaching of motor and sport activities (M-EDF / 01 and M- EDF / 02) expressed in the three-year class (L22 Physical activity and Sport Sciences), which already foresee to acquire a specific preparation to access the masterly degree classes (LM68 - Sport Science and Techniques, LM67 - Sciences of the Adaptive Preventive Motor Activities and LM47 - Organization and management of services for sports and motor activities) for the training of teachers of physical education in secondary schools of first and second grade, proposing a development of knowledge, skills and specific competences and oriented to the didactic-educational and training methods in the motor and sports field both on the vertical plan (between three-year and masterly courses) that horizontal (in the relationship between University and CONI). On the vertical plane interesting perspectives could emerge for the internal articulation of the study courses for a part of the M-EDF teachers and so to assume, at all three-year courses of motor science in Italy, specific didactic connotations and methodologies for the teaching of motor and sport activities in the developmental age. On the horizontal plan, on the other hand, the relationship between the University and CONI could offer a joint response to the growing demand for professionalization of motor-sports operators, by talking about training and professional qualification systems, starting from the National System of Qualifications of Sport Technicians (SNAQ) elaborated with reference to the context CONI-National Sports Federations Associate Sports Disciplines, enhancing the possible synergies with the other organizations involved in the training of the various professional figures operating in the world of sport and motor activities. The SNAQ System presents some characteristics that are highly compatible with the Italian university system and which could be enhanced to favour inter-institutional dialogue:

- the articulation of training in four different levels of qualification with different functions, tasks and responsibilities;

- a training defined by the achievement of the skills necessary to best perform the functions envisaged for each level;

- recognition, in the technic training course, of the experience gained and the skills achieved even in nonformal areas;

- the put into effect of a credits system, valorising their recognition and transferability;

- the introduction of a double certification: the qualification and the abilification, with the consequent attention to the importance of ongoing formation;

- openness to other professionals who may have parallel training paths or integrated with those of the sports technicians.

These interventions could outline wider horizons in the specialization, training and continuous professional development of the teacher of physical education in Italy which, aligning itself with European best practices, will allow translating the political purposes of physical and sport education into effective school practices. In conclusion, a new approach in teacher training could foster a broad advance in specialization and professional development of physical education teacher, adjusting our educational path to the European best practices (Eurydice, 2013).

\section{REFERENCES}

Altavilla, G., Di Tore, P.A., Riela, L., D'Isanto, T. (2017) Anthropometric, physiological and performance aspects that differentiate male athletes from females and practical consequences Journal of Physical Education and Sport, 17, art. no. 226, pp. 2183-2187. 
Bauman E. (1887) Guida illustrata per l'insegnamento della ginnastica nelle scuole normali ed elementari femminili - parte seconda, Roma, F. G. Valle Editore.

Crivellari C. (2004). Professori nella scuola di massa. Dalla crisi del ruolo alla formazione universitaria. Roma: Armando.

D'Isanto, T. (2016) Pedagogical value of the body and physical activity in childhood, Sport Science, 9, pp. 13-18.

D'Isanto, T., Di Tore, P.A. (2016) Physical activity and social inclusion at school: A paradigm change, Journal of Physical Education and Sport, 16, pp. 1099-1102.

Di Tore, P.A., Schiavo, R., D'Isanto, T. (2016) Physical education, motor control and motor learning: Theoretical paradigms and teaching practices from kindergarten to high school, Journal of Physical Education and Sport, 16 (4), art. no. 205, pp. 1293-1297.

Gaetano, A. (2016) Relationship between physical inactivity and effects on individual health status, Journal of Physical Education and Sport, 16, pp. 1069-1074.

Gaetano, R. (2012) Motor learning and didactics into physical education and sport documents in middle school-first cycle of education in Italy, Journal of Physical Education and Sport, 12 (2), pp. 157-163.

Gentile, E. (2004) Fascismo. Historia e Interpretación.

Gentile, E. (1993) II Culto Del Littorio.

Gentile, E. Fascism as political religion (1990) Journal of Contemporary History, 25 (2-3), pp. 229-251. Tiziana, D., Antonetta, M., Gaetano, A. (2017) Health and physical activity, Sport Science, 10 (1), pp. 100-105.

Lautenbach, F., Antoniewicz, F. (2018) Ambivalent implicit attitudes towards inclusion in preservice PE teachers: The need for assessing both implicit and explicit attitudes towards inclusion, Teaching and Teacher Education, 72, pp. 24-32. https://doi.org/10.1016/j.tate.2018.01.003

Michael, R.D., Webster, C.A., Egan, C.A., Stewart, G., Nilges, L., Brian, A., Johnson, R., Carson, R., Orendorff, K., Vazou, S. (2018) Viability of university service learning to support movement integration in elementary classrooms: Perspectives of teachers, university students, and course instructors Teaching and Teacher Education, 72, pp. 122-132. https://doi.org/10.1016/j.tate.2018.03.003

Raiola, G. (2017) Motor learning and teaching method, Journal of Physical Education and Sport, 17, art. no. 236, pp. 2239-224.

Raiola, G., Di Tore, P.A. (2017) Motor learning in sports science: Different theoretical frameworks for different teaching methods, Sport Science, 10, pp. 50-56.

Raiola, G. (2013) Body knowledge and motor skills, Knowledge Cultures, 1 (6), pp. 64-72.

Sinclair, C., Thornton, L.J. (2018) Exploring preservice teachers' conceptions after 'living a hybrid curriculum', European Physical Education Review, 24 (2), pp. 133-151. https://doi.org/10.1177/1356336X16669331

Keating, X.D., Shangguan, R., Zhou, K., Fan, Y., Liu, J., Harrison, L. (2017) Research on preservice physical education teachers' and preservice elementary teachers' physical education identities: A systematic review, Journal of Teaching in Physical Education, 36 (2), pp. 162-172. https://doi.org/10.1123/jtpe.2016-0128

Kwon, J.Y., Kulinna, P.H., van der Mars, H., Koro-Ljungberg, M., Amrein-Beardsley, A., Norris, J. (2018) Physical Education Preservice Teachers' Perceptions About Preparation for Comprehensive School Physical Activity Programs Research Quarterly for Exercise and Sport, pp. 1-14. Article in Press.

Pasqualini, M. (2014) Youth as a model of Italian fascism: Physical education, medical discourse and body cult in the opera nazionale Balilla, 1930-1937 Historia Social, (82), pp. 49-72.

Ledeen, M.A. (1969) Italian fascism and youth Journal of Contemporary History, 4 (3), pp. 137-154. https://doi.org/10.1177/002200946900400309 
Cassata, F. Building (2011) The new man: Eugenics, racial science and genetics in twentieth-century Italy Building the New Man: Eugenics, Racial Science and Genetics in Twentieth-Century Italy, pp. 1-428. https://doi.org/10.7829/9789639776838

Gillette, A. Racial Theories in Fascist Italy (2002) Racial Theories in Fascist Italy. https://doi.org/10.4324/9780203279212

Ponzio, A. (2008) A forgotten story: The training for teachers of physical education in Italy during the fascist period Sport in Society, 11 (1), pp. 44-58. https://doi.org/10.1080/17430430701717681

Santoni Rugiu A., Santamaita S. (2011). II professore nella scuola italiana dall'Ottocento a oggi. Bari: Laterza.

Ulmann J. (2004). Nel mito di Olimpia. Ginnastica, educazione fisica e sport dall'antichità ad oggi. Roma: Armando.

\section{Reference Document}

Law n. 88, 7 febbraio 1958, Provvedimenti per l'educazione fisica.

Law n. 4442, July 7, 1878, Obbligatorietà dell'insegnamento della ginnastica educativa nelle scuole.

Legislative decree 13 aprile 2017, n. 59. Riordino, adeguamento e semplificazione del sistema di formazione iniziale e di accesso nei ruoli di docente nella scuola secondaria per renderlo funzionale alla valorizzazione sociale e culturale della professione.

Ministerial decree 10 settembre 2010, n. 249. Regolamento concernente: «Definizione della disciplina dei requisiti e delle modalità della formazione iniziale degli insegnanti della scuola dell'infanzia, della scuola primaria e della scuola secondaria di primo e secondo grado, ai sensi dell'articolo 2, comma 416, della legge 24 dicembre 2007, n. 244».

RECOMMENDATION OF THE EUROPEAN PARLIAMENT AND OF THE COUNCIL of 18 December 2006 on key competences for lifelong learning, (2006/962/EC) Official Journal of the European Union.

Sistema Nazionale delle Qualifiche dei Tecnici Sportivi SNAQ (National System of Qualifications of Sport Technicians,) 10 giugno, 2014, CONI.

Commissione europea/EACEA/Eurydice, 2013. Educazione fisica e sport a scuola in Europa. Rapporto Eurydice. Lussemburgo: Ufficio delle pubblicazioni dell'Unione europea.

\section{(9) $(\Theta \Theta \Theta$}

This title is licensed under a Creative Commons Attribution-NonCommercial-NoDerivs 4.0 Unported License. 